\title{
Production of Bacterial Amylase and Evaluation for Starch Hydrolysis
}

\author{
Eleni Belay*, Medhanit Teshome \\ School of Graduate Studies, Microbial, Cellular, and Molecular Biology Department, Addis Ababa University, Addis Ababa, Ethiopia
}

Email address:

Elenibelay559@gmail.com (E. Belay), medanit3@gmail.com (M. Teshome)

${ }^{*}$ Corresponding author

\section{To cite this article:}

Eleni Belay, Medhanit Teshome. Production of Bacterial Amylase and Evaluation for Starch Hydrolysis. International Journal of Microbiology and Biotechnology. Vol. 6, No. 2, 2021, pp. 34-44. doi: 10.11648/j.ijmb.20210602.12

Received: February 10, 2021; Accepted: March 24, 2021; Published: April 20, 2021

\begin{abstract}
In starch degrading industry, the first step to be performed is gelatinization of starch granules at elevated temperature. This process tends to form a viscose suspension, thus making mixing and pumping a huge challenge. Therefore, to lower the viscosity of starch paste thermostable enzymes are added for breaking down the polysaccharides into oligosaccharides by a process known as liquefaction. Therefore, the availability of these enzymes can be considered a prerequisite to start successful starch liquefaction and saccharification industry. The main objective of this study was, therefore, to produce efficient microbial amylolytic enzymes for starch hydrolysis. One bacterial isolate designated as BACC 2107 was isolated from locally collected samples. The enzyme has optimum activity at $\mathrm{pH}$ of 5.0 and $70^{\circ} \mathrm{C}$. The addition of calcium in the reaction mixture was shown to stabilize the enzyme. The isolate BACC 2107 was able to grow under solid-state fermentation (SSF) using wheat bran as a solid substrate. Optimum enzyme production was recorded at $32^{\circ} \mathrm{C}$, and at $120 \mathrm{~h}$ of incubation and at a moisture content of $75 \%$. Addition of peptone to the SSF medium as an organic nitrogen supplement enhanced enzyme production. The enzyme was used to hydrolyze a $25 \%(\mathrm{w} / \mathrm{v})$ of starch at $70^{\circ} \mathrm{C}$ and $\mathrm{pH} 5.0$, and the resulting hydrolysate was analyzed on TLC plates. After $4 \mathrm{~h}$ hydrolysis, the TLC chromatogram showed the release of glucose, maltose, maltotriose, and other oligosaccharides, indicating that the enzyme is endo-acting alpha-amylase. The results of this study show that amylase from BACC 2107 has a good potential to be used in starch liquefaction and saccharification processes. The ability of the isolate to grow and produce the enzyme under SSF using cheap agro-industrial wastes could help to greatly reduce the production cost of the enzyme.
\end{abstract}

Keywords: Alpha-Amylase, Liquefying, $\mathrm{Ca}^{2+}$-Dependent, Starch Hydrolysis

\section{Introduction}

Starch is a polysaccharide made of glucose molecules linked together with an alpha-D-(1-4) linkage and alpha-D(1-6) linkages at branching points [1]. Apart from its food use, starch can be used in different applications such as the paper and textile industries, pharmaceuticals, adhesives, beverages, plastics, and such derivatives as dextrin and nitro starch [2]. Commercially, starch is isolated from such agricultural crops as tubers (potato), cereals (e.g maize, sorghum, millet, and rice), and root (cassava, sweet potato, arrowroot) [3]. In Ethiopia agriculture is considered the backbone of the national economy. Among the common crops in Ethiopia that can serve as a commercial source of starch include enset [4], Ethiopian yam [5], godare [6], anchote [7], cassava [8], and kottee harree [9].

Starch can be hydrolyzed both enzymatically and chemically. Chemically, starch is converted into ordinary glucose and glucose syrup by mixing wetted starch with a weak solution of hydrochloric acid and heating it under pressure [10]. Enzymatically, amylases are used to break down the glycosidic bonds of the starch [11]. Upon hydrolysis, starch is converted to a variety of derivatives such as glucose, maltose, and syrups of various dextrose levels [12].

From a commercial and environmental point of view, many of the chemical processes used in starch processing industries have inherent drawbacks [13]. As a result, the use of enzymes as industrial catalysts offers a better option and is gradually replacing chemical catalysts [14]. At the moment, the presence of a large number of microbial amylases is almost completely 
replacing the chemical hydrolysis of starch in the starch processing industry. On the other hand, recent advancements in biotechnology enabled the use of amylase enzymes to expand in many fields of application, including the food, fermentation, and pharmaceutical industries [15].

Amylolytic enzymes can be obtained from microorganisms, plants, and animals [16]. However, at present, a larger part of the commercial amylases is obtained from microorganisms, mainly from the genus Bacillus and actinomycetes genera like Thermonspra and Thermonactinomyces), fungi (mainly from the genera Aspergillus and Penicillium) [16]. The different amylases used for industrial application are alpha-amylase, betaamylase, and glucoamylase [17]. These enzymes are used as detergent additives, as desizing agents in the paper and textile industries, beverages, fuel ethanol production, food fermentation, and as analytical reagents [18].

In the starch processing industry, enzymes are used in the conversion of starch into high fructose corn syrup. Thus, for complete conversion of starch into high glucose syrup, the starch must pass through a three-step process, namely gelatinization, liquefaction, and saccharification. In the liquefaction process, the starch undergoes soluble oligomaltodextrins. The starch slurry (30-35\%) of $\mathrm{pH} 6$ is mixed with $\alpha$-amylase and passed through a jet cooker and kept in a temperature range $\left(95-105^{\circ} \mathrm{C}\right)$ for $90 \mathrm{~min}$ to assure the removal of lipid-starch complexes. In this process, the dextrose equivalent value of starch hydrolysate syrup depends on the time of incubation and the amount of enzyme added. In this process, the drawback of using primitive $\alpha$-amylases is that they are not active at a $\mathrm{pH}$ below 5.9 and at the high temperatures level. Therefore, the $\mathrm{pH}$ of the starch slurry has to be adjusted from the natural $\mathrm{pH}$ of 4.5 to $\mathrm{pH} 6$, and calcium must be added to stabilize the enzyme [19]. Therefore, there is a need to develop $\alpha$-amylases having enhanced thermostability, tolerant to acidic $\mathrm{pH}$ values, and $\mathrm{Ca}^{2+}$ independent [18]. The advantages of using these thermostable $\alpha$ amylases in industrial processes include decrement in the risk of contamination, an increased diffusion rate of starch slurry, and also decrement in the cost of external cooling.

The stability of enzymes is also another limiting factor in the selection of enzymes for industrial applications due to the elevated temperature or extreme $\mathrm{pH}$ of many biotechnological processes. In regard to this, there is a continuing demand to improve the stability of the enzymes and thus meet the requirements set by specific applications, which become a huge interest for searching for a new enzyme that is cost-effective and suitable for applications. Protein engineering is also the other option in finding thermostable enzymes [20]. However, our present day knowledge and available technology in relation to protein structure and function are incomplete to use the tools of protein engineering to develop novel enzymes. Another option is, therefore, to look for better enzymes from nature. The aim of this study was, therefore, to isolate new thermostable amylase producing microbial isolates for the production of the enzyme using cheap agro-industrial wastes.

\section{Materials and Methods}

\subsection{Media and Culture Conditions for Isolation, Screening and Enzyme Production for Amylolytic Organisms}

Bacterial isolates were obtained from a water sample collected from hot spring water at Afdera, Afar region, Ethiopia, and soil samples collected from Addis Ababa University Arat Kilo campus. The water sample was diluted using $20 \mathrm{ml}$ of sterile distilled water and $5 \mathrm{ml}$ of the water sample was aseptically transferred into a $250 \mathrm{ml}$ Erlenmeyer flask containing $50 \mathrm{ml}$ sterile enrichment liquid medium with the composition of $(\mathrm{g} / \mathrm{l})$ : soluble starch 1.25 ; peptone 0.5 ; yeast extract $0.5 ; \mathrm{CaCl}_{2} .2 \mathrm{H}_{2} \mathrm{O} \quad 0.1 ; \quad \mathrm{MgSO}_{4} .7 \mathrm{H}_{2} \mathrm{O} \quad 0.1$; $\mathrm{K}_{2} \mathrm{HPO}_{4} 0.5 ; \mathrm{NaCl} 2.5 ; 50 \mathrm{ml}$ of soil extract. The flask was then incubated on a shaker at $45^{\circ} \mathrm{C}-55^{\circ} \mathrm{C}$. After $24 \mathrm{~h}$ incubation, $1 \mathrm{ml}$ of culture was taken and serially diluted $\left(10^{-}\right.$ ${ }^{1}-10^{-7}$ ) with sterile distilled water. Thereafter, $100 \mu$ l of the diluted culture was inoculated and spread on sterilized agar plates aseptically, with the same enrichment media composition mentioned in the above with the addition of 7.5 $(\mathrm{g} / \mathrm{l})$ agar. The plates were then placed in an incubator and incubated at $45^{\circ} \mathrm{C}$ for $48 \mathrm{~h}$. Isolation from the soil sample was carried out as follows. First, $1 \mathrm{~g}$ of soil was mixed with 9 $\mathrm{ml}$ of sterile water, and then serially diluted $\left(10^{-1}-10^{-7}\right)$ with sterile distilled water. One hundred $\mu$ of the diluted culture was spread on agar plates. The media used for the growth of bacterial isolates was composed of $(\mathrm{g} / \mathrm{l})$ : peptone 1.5 , yeast extract 2.5; soluble starch 2.5; $\mathrm{MgSO}_{4} .7 \mathrm{H}_{2} \mathrm{O} 0.1 ; \mathrm{NaCl} 2.5$; $\mathrm{K}_{2} \mathrm{HPO}_{4} 0.3 ; \mathrm{KH}_{2} \mathrm{PO}_{4} 0.2 ; \mathrm{CaCl}_{2} .2 \mathrm{H}_{2} \mathrm{O} 0.05$. For solid media $7.5(\mathrm{~g} / \mathrm{l})$ agar was added and incubated at $32^{\circ} \mathrm{C}[23,24]$. After $48 \mathrm{~h}$ incubation, distinct colonies were picked and streaked on freshly prepared agar plates and incubated for 48h. For fungal isolation, soil samples and plant samples were collected from different environments. First, the plant samples were cleaned with $75 \%$ ethanol for 1 min then washed with 3\% hypochlorite for $3 \mathrm{~min}$ after this, cleaned with $96 \%$ ethanol for $30 \mathrm{~min}$. In the end, cleaned three times with sterile distilled water and cut the edge of the plant and, put on solid media agar. The root of the plants was firstly cleaned with $75 \%$ ethanol for 3 min then cleaned by $3 \%$ hypochlorite for $10 \mathrm{~min}$. After this, it was cleaned with $96 \%$ of ethanol for 2 min lastly cleaned three times with sterile distilled water and cut down the edges of the root of the plant and, put on solid media agar with the same media composition as mentioned in the bacterial growth media with the addition of $0.05(\mathrm{~g} / \mathrm{l})$ of chloramphenicol [25]. The plates were placed in an incubator and incubated at $32^{\circ} \mathrm{C}$ for $168 \mathrm{~h}$. The soil sample was grounded and $1 \mathrm{~g}$ of soil sample was serially diluted $\left(10^{-1}-10^{-7}\right)$ with sterile distilled water. Then, $100 \mu \mathrm{l}$ of the diluted culture was inoculated and spread on agar plates aseptically and placed in an incubator and incubated at $30^{\circ} \mathrm{C}$ for $168 \mathrm{~h}$. After successive rounds of purification pure isolates were obtained [21, 22].

\subsection{Screening for Amylase Productions}

To select amylase producing strains all fungal and bacterial 
isolates were grown on solid media. Then the isolates were screened for amylase production by flooding the agar plates with Lugol's Iodine solution ( $1 \mathrm{~g}$ iodine and $2 \mathrm{~g}$ of potassium iodide in $100 \mathrm{ml}$ of distilled $\mathrm{H}_{2} \mathrm{O}$ ) [26]. The appearance of a clear zone around the colonies indicated the production of the amylolytic enzymes. The positive isolates for screening were grown in liquid media $(50 \mathrm{ml}$ broth in $250 \mathrm{ml}$ capacity Erlenmeyer flasks) on a shaker incubator, $120 \mathrm{rpm}$. The bacterial isolates were grown at $32^{\circ} \mathrm{C}$ in shaker incubator for $48 \mathrm{~h}$ while the fungal isolates were grown at $30^{\circ} \mathrm{C}$ for $168 \mathrm{~h}$. The crude enzyme of both bacterial and fungal cultures was harvested by centrifugation at $10,000 \mathrm{rpm}$ for $10 \mathrm{~min}$ in the centrifuge. The supernatant was harvested, which was used as a crude enzyme and, stored under a refrigerator $\left(-22^{\circ} \mathrm{C}\right)$. The crude 16 enzymes from the selected bacterial isolates and fungal isolates were assayed with the standard enzyme assay method described in (section 2.5) with phosphate buffers, $\mathrm{pH} 7.00$ (final concentration of $50 \mathrm{mM}$ ) in the absence of $5 \mathrm{mM} \mathrm{CaCl} \mathrm{Cl}_{2}$ solution and incubated in a water bath with a temperature range of $(50-85)^{\circ} \mathrm{C}$ with a slight modification of Mc Tigue et al. 's study [27]. Then the selected isolate for maximum production of the enzyme was preserved on agar slants.

\subsection{Biochemical and Morphological Characterization of BACC 2107}

\subsubsection{Gram Reaction, Microscopic Examination and Morphology of Colony}

To test the organism for gram reaction the organism was fixated on the slide. Consequently, the slide was immersed in crystal violate solution for $1 \mathrm{~min}$ and it was instantly washed for 5 min by running water. Next, the slide was put in iodine containing solution for $1 \mathrm{~min}$ then washed by running water for $5 \mathrm{~min}$. Subsequently, the slide was deepened in $96 \%$ of ethanol for $30 \mathrm{sec}$ and then washed away by running water. After this, the slide was immersed in saffranine for $1 \mathrm{~min}$ and washed by running water for $5 \mathrm{~min}$. Finally, the slide was observed under the microscope [28].

\subsubsection{Catalase Test}

The catalase reaction was determined by adding $3 \% \mathrm{H}_{2} \mathrm{O}_{2}$ drop by drop on a liquid culture media grown for $48 \mathrm{~h}$ and mounted on a slide and the presence or absence of bubbles or foam formation was observed.

\subsection{Solid-state Fermentation (SSF) Medium for Bacterial Amylase Production}

SSF media was used for enzyme production for the selected isolates using wheat bran as a sole carbon source with the addition of the following nutrients $\mathrm{g}$ in $13 \mathrm{ml}$ of distilled water (\%): $\mathrm{NaCl} 0.5 ; \mathrm{CaCl}_{2} .2 \mathrm{H}_{2} \mathrm{O} 0.01 ; \mathrm{MgSO}_{4} .7 \mathrm{H}_{2} \mathrm{O} 0.02 ; \mathrm{KH}_{2} \mathrm{PO}_{4}$. 1 ; $10 \mathrm{~g}$ wheat bran was moistened with the above nutrient solution to a moisture level of $60 \%$ (v/w ratio) in $250 \mathrm{ml}$ Erlenmeyer flasks for the cultivation of the bacterial isolates. After sterilization, each SSF media was inoculated with $2 \mathrm{ml}$ of overnight-cultured inoculums of bacterial isolates. They were incubated in an incubator at $32^{\circ} \mathrm{C}$ for $120 \mathrm{~h}$. The crude enzyme from SSF media was harvested by adding $100 \mathrm{ml}$ of distilled water and shaken for $1 \mathrm{~h}$ at $120 \mathrm{rpm}$ on the shaker, then filtered using a cotton sheet [29].

\subsection{Enzyme Assay}

The enzyme assay was carried out using the dinitro salicylic acid (DNS) method [30]. The assay mixture was composed of $1 \%$ starch dissolved in $50 \mathrm{mM}$ acetate buffer, pH 5.0 (or phosphate buffer, $\mathrm{pH} 7.0$ ). To $0.9 \mathrm{ml}$ of the assay substrate, $0.1 \mathrm{ml}$ of the diluted enzyme was added and incubated at $70^{\circ} \mathrm{C}$ for $10 \mathrm{~min}$ in a water bath. The reaction was stopped by adding $2 \mathrm{ml}$ of DNS solution followed by boiling for exactly $5 \mathrm{~min}$. After cooling in running water for about $5 \mathrm{~min}$, the optical density of the resulting colored solution was measured at $540 \mathrm{~nm}$ against a reagent blank.

\subsection{Enzyme Characterization}

\subsubsection{Effect of $\mathrm{pH}$ on the Activity of Amylase}

To determine the $\mathrm{pH}$ profile of the bacterial amylase enzyme, the enzyme was assayed using $2 \%$ soluble starch in 3 buffer systems pH 3.5 to 9.0 (final concentration $50 \mathrm{mM}$ ). The buffers are acetate buffer $(\mathrm{pH} \mathrm{3.5,4.0,} \mathrm{4.5,} \mathrm{5.0,} \mathrm{5.5),}$ phosphate buffer ( $\mathrm{pH} 5.5,6.0,6.5,7.0,7.5$ and 8.0) and Tris buffer ( $\mathrm{pH} 7.5,8.0,8.5$ and 9.0). To determine the effect of $\mathrm{pH}$ on enzyme stability, the crude enzyme was diluted by acetate buffer $\mathrm{pH} 5.00$ (v/v enzyme: buffer 1:10). The diluted enzyme was mixed with different buffer systems with a final concentration of $50 \mathrm{mM}$, then enzyme was assayed in the same procedure mentioned in (section 2.5) but, the enzyme was incubated at $60^{\circ} \mathrm{C}$ in a water bath.

\subsubsection{Effect of Temperature on the Activity Amylase Enzyme with or Without $\mathrm{Ca}^{2+}$}

To determine the effect of temperature on the activity of amylases, the crude enzyme from the bacterial isolate was diluted by acetate buffer $\mathrm{pH} 5.00$ (v/v enzyme: buffer 1:10) and assayed in temperature ranges of $45-85^{\circ} \mathrm{C}$ (within $5^{\circ} \mathrm{C}$ intervals). The assay methods used for the bacterial enzyme was mentioned in (section 2.5), but the substrate solution was prepared in $50 \mathrm{mM}$ acetate buffer $\mathrm{pH} 5.00$. Then the residual activity of the enzyme was determined by assaying the incubated enzyme as mentioned above. The $\mathrm{Ca}^{2+}$ requirement of a bacterial enzyme on the effect of temperature was determined by incubating the enzyme at a temperature range of $45-85^{\circ} \mathrm{C}$ (within $5^{\circ} \mathrm{C}$ intervals) with $5 \mathrm{mM} \mathrm{CaCl}_{2}$ solution. After incubation, the residual activity was determined [31].

\subsubsection{The thermostability of the Amylase Enzyme with or Without $\mathrm{Ca}^{2+}$}

The thermostability of the bacterial amylase enzyme was determined after incubating the enzyme at temperature values of 70 and $75^{\circ} \mathrm{C}$ for $1 \mathrm{~h}$ in a water bath. First, each labeled eppendorf filled with enzyme was placed in the water bath and the other eppendorf was taken out and stored in a refrigerator $\left(+4^{\circ} \mathrm{C}\right)$ at $10 \mathrm{~min}$ interval. After incubation, the enzyme was diluted $(1: 10(\mathrm{v} / \mathrm{v})$ ratio) with acetate buffer $\mathrm{pH} 5.00$ (final concentration of $50 \mathrm{mM}$ ) then assayed and residual activity 
was determined. To determine the $\mathrm{Ca}^{2+}$ requirement for thermal stability of the bacterial enzyme, the crude enzyme was incubated at a temperature of $75^{\circ} \mathrm{C}$ for $1 \mathrm{~h}$ in the water bath with $5 \mathrm{mM} \mathrm{CaCl}_{2}$ solution. After incubation, the enzyme was assayed and residual activity was determined [32].

\subsection{Thin Layer Chromatographic (TLC) Analysis of Reaction Products}

To identify the type of amylase enzyme produced by the bacterial isolate. The reaction mixture was made of $25 \%(\mathrm{w} / \mathrm{v})$ raw starch mixed with $22.8 \mathrm{U}$ concentrated crude enzyme from the bacterial isolate and $10.85 \mathrm{U}$ of malt enzyme extracted using (section 2.9) method which was incubated at 70 and $60^{\circ} \mathrm{C}$ for $4 \mathrm{~h}$ in the water bath but the malt enzyme was included in the reaction after $3 \mathrm{~h}$ of the incubation period. One $\mathrm{ml}$ of the hydrolysate was collected in an eppendorf within $1 \mathrm{~h}$ interval and stored in a refrigerator $\left(4^{\circ} \mathrm{C}\right)$. Then the hydrolysate was spotted on the TLC plate along with standard known sugar (glucose and maltose) solutions (as used by [33] with some modification). A one dimensional ascend was done using a solvent system (v/v) of butanol: ethanol: water (5:5:2). After a total of 4 ascends air-dry TLC plates were sprayed with $50 \%(\mathrm{v} / \mathrm{v})$ methanol- $\mathrm{H}_{2} \mathrm{SO}_{4}$ mixture and heated for $5 \mathrm{~min}$ at about $160^{\circ} \mathrm{C}$. The dark brown sugar spots that appeared were identified by comparing with the standards.

\subsection{Optimization of Culture Conditions for Amylase Production of BACC 2107}

\subsubsection{Time Course of Enzyme Production}

The maximum period for the production of the bacterial enzyme was determined by growing the bacterial isolate on SSF media (section 2.4 ) at $32^{\circ} \mathrm{C}$. The relative activity of the enzyme was measured after 24, 48, 72, 96, 120, and $144 \mathrm{hrs,}$ respectively. By harvesting the enzyme from cultivating flasks at a time [29].

\subsubsection{Effect of Moisture Level on Enzyme Production}

The optimum moisture level for amylase enzyme production of the bacterial isolate was determined by growing bacterial isolate in SSF media at $32^{\circ} \mathrm{C}$ at a moisture level (v/w) of $33.3 \%$, $50 \%, 60 \%, 66.7 \%$ and $75 \%$. Then the enzyme was harvested after $120 \mathrm{~h}$ of incubation period and assayed to determine the enzyme activity of the bacterial isolate [34].

\subsubsection{Effect of Nitrogen Source on Enzyme Production}

The appropriate nitrogen source for amylase enzyme production of the bacterial isolate was produced by growing the bacterial isolate in SSF media within $75 \%(\mathrm{v} / \mathrm{w})$ with the following nitrogen sources: inorganic nitrogen source $\left(\mathrm{NH}_{4}\left(\mathrm{So}_{4}\right)_{2}\right.$ and $\left.\mathrm{NaNO}_{3}\right)$ and organic nitrogen source (peptone and yeast extract) and also without a nitrogen source. After 120 $\mathrm{h}$ of incubation the crude enzyme was harvested and assayed to determine the enzyme activity $[35,36]$.

\subsection{Beta-amylase Extraction and Enzyme Hydrolysis of Raw Starch}

Beta amylase was extracted from a barely malt flour following the method of Buttimer et al., 1998 with slight modification [37]. To $0.5 \mathrm{~g}$ malt powder, $5 \mathrm{ml}$ of acetate buffer ( $\mathrm{pH}$ 5.0) was added and intermittently vortex mixed for $1 \mathrm{~h}$. The mixture was then incubated in a refrigerator $\left(+4^{\circ} \mathrm{C}\right)$ for 5 min followed by centrifugation at $12,000 \mathrm{rpm}$ for $5 \mathrm{~min}$. The supernatant was collected and kept at $\left(+4^{\circ} \mathrm{C}\right)$ until used.

A $2 \mathrm{~g}$ of raw potato starch was mixed with $6 \mathrm{ml}$ acetate buffer, $\mathrm{pH} 5.0$ containing $10 \mathrm{mM} \mathrm{CaCl}_{2}$. Then 22.8 Units of concentrated crude bacterial enzyme preparation and incubated at $70^{\circ} \mathrm{C}$. After $3 \mathrm{~h}$ the reaction mixture was taken out, $10.85 \mathrm{U}$ of malt enzyme extract was added, and incubated at $60^{\circ} \mathrm{C}$ for a further $4 \mathrm{~h}$. At $1 \mathrm{~h}$ interval $1 \mathrm{ml}$ of the hydrolysate was collected in eppendorf and stored $\left(+4^{\circ} \mathrm{C}\right)$ and the amount of reducing sugar was measured following the DNS method after 1:200 dilution with distilled water [38, 39].

\subsection{Drop in Starch Viscosity}

In order to measure the viscosity of the starch hydrolysates produced by alpha amylase, the following method was used. $3 \mathrm{ml}$ of water was taken in a funnel sealing it at the bottom. It was then released to flow downward and the speed was measured in time. The water completed its flow in 9 seconds. Using this method, the flow of the starch hydrolysates in 9 seconds was measured in volume.

\section{Result}

\subsection{Isolation and Screening of Organisms}

A total of 289 (226 bacterial and 63 fungal) isolates were screened for amylolytic activity on starch-agar plates. A total of 180 isolates (130 bacterial isolate and 50 fungal isolates) were positive for extracellular amylase production. The activities of fungal enzymes were very low compared to the bacterial enzymes. Based on this, bacterial isolates were further evaluated for the level of amylase production based on the diameter of the halo zone formed (Figure 1).

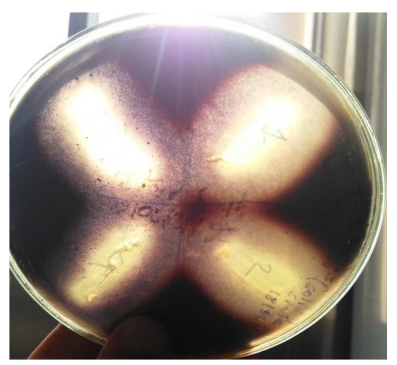

Figure 1. Clear zone formed around bacterial colonies after flooding them with Lugol's iodine regent.

To select the best amylase producing isolate (s) all the 180 positive isolates on starch agar was grown in liquid media and the relative activity of the crude enzyme was assayed at $50^{\circ} \mathrm{C}-85^{\circ} \mathrm{C}$.

Four of the amylase enzymes from the bacterial isolates were found to be active at $70^{\circ} \mathrm{C}$. When thermostability of the four enzymes that were tested and compared, only one bacterial isolate designated as BACC 2107 produced an enzyme that was 
more heat stable and selected for further study.

\subsection{Biochemical and Morphological Characterization of Isolate BACC 2107}

For gram reaction the organism was found to be rod shape and purple in color when seen under microscope. This, indicates that the organism was gram positive bacteria. In catalase reaction, the organism was able to produce a gas (oxygen) bubble indicating the organism was able to produce catalase enzyme. On the other hand, the colonies of the organism were yellow, creamy, and circular edged.

Table 1. Summary of the biochemical and morphological features of isolate BACC 2107.

\begin{tabular}{llc}
\hline Parameter & Observation & Result \\
\hline 1. Gram reaction & Purple in color & Gram positive \\
2. Catalase test & Produce a gas bubble & Catalase positive \\
3. Microscopic exam. & Rod shape & \\
4. Colony features & Yellow, Creamy, Circular edged & \\
\hline
\end{tabular}

\subsection{Properties of the Enzyme}

\subsubsection{Effect of pH on Activity of Amylase}

For determination of $\mathrm{pH}$ profile, the bacterial amylase enzyme was assayed in 3 buffer systems with a $\mathrm{pH}$ range of $3.5-9.0$. Based on this, the optimum $\mathrm{pH}$ of the enzyme was observed at $\mathrm{pH}$ 5.0. The least activity of the enzyme was observed at $\mathrm{pH} 3.5$ (Figure 2).

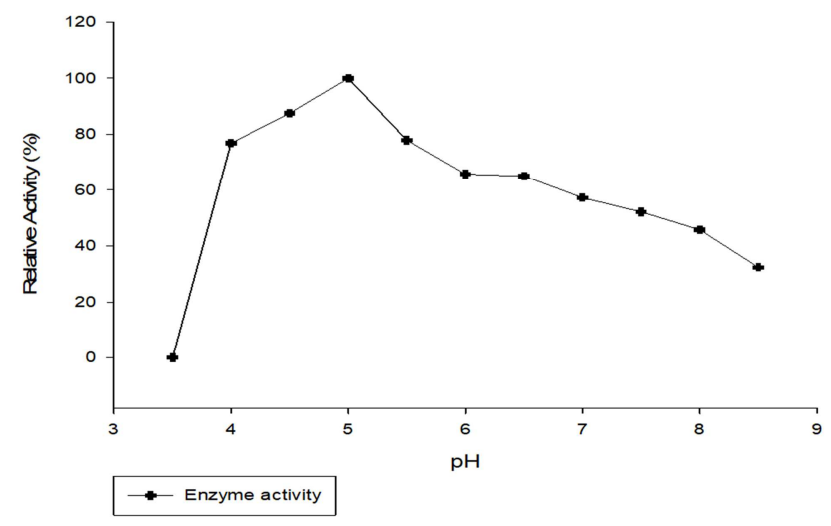

Figure 2. Effect of $\mathrm{pH}$ on the activity of BACC 2107 amylase.

\subsubsection{Effect of Temperature on Activity and Stability of Amylase}

To test the thermal activity and calcium requirement of BACC 2107 amylase, the crude enzyme was assayed in temperature ranges of $45-85^{\circ} \mathrm{C}$ with and without $5 \mathrm{mM} \mathrm{Ca}^{+2}$. The optimum relative activities of the enzyme were measured in the absence of $5 \mathrm{mM} \mathrm{Ca}^{+2}$ in a temperature range of $55-65^{\circ} \mathrm{C}$. Maximum activity was recorded at $70^{\circ} \mathrm{C}$ and after $75^{\circ} \mathrm{C}$ the relative activity of the enzyme started to decline as shown in (Figure 3). In the presence of $5 \mathrm{mM} \mathrm{Ca}^{+2}$, the maximum activity of the enzyme was recorded at $65^{\circ} \mathrm{C}(100 \%)$. The relative activity measured at $70^{\circ} \mathrm{C}$ and $75^{\circ} \mathrm{C}$ was $92.81 \%$ and $70.76 \%$, respectively. This result showed that the enzyme activity in the presence of $5 \mathrm{mM} \mathrm{Ca}^{+2}$ after $70^{\circ} \mathrm{C}$ tend to decline slowly, showing that the enzyme was more stable in the presence of $5 \mathrm{mM} \mathrm{Ca}^{+2}$ (Figure 3 ).

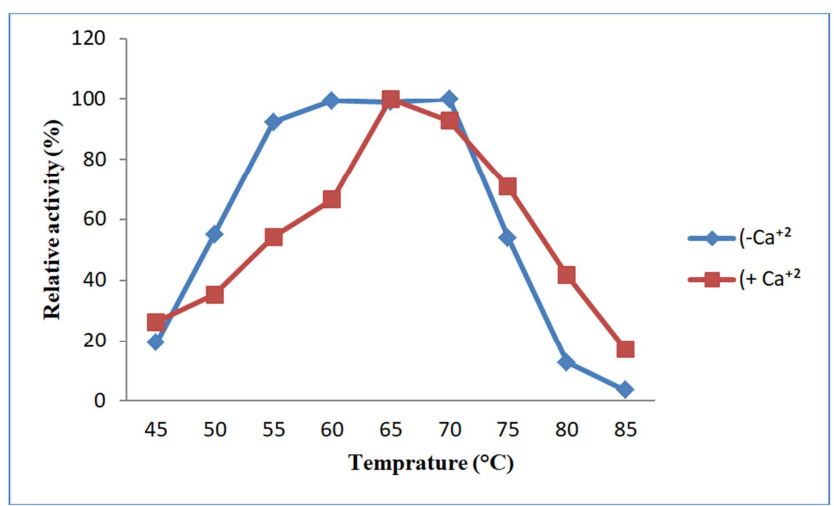

Figure 3. Effect of temperature on the activity of BACC 2107 enzyme in the presence and absence of $\mathrm{Ca}^{+2}$.

The thermal stability of bacterial amylase enzyme was determined by incubating the enzyme for $60 \mathrm{~min}$ in the presence and absence of $5 \mathrm{mM} \mathrm{Ca}^{+2}$ in the temperature values of $70^{\circ} \mathrm{C}$ and $75^{\circ} \mathrm{C}$. In the absence of $\mathrm{Ca}^{+2}$ and $70^{\circ} \mathrm{C}$, the enzyme retained about $24.51 \%$ of its original

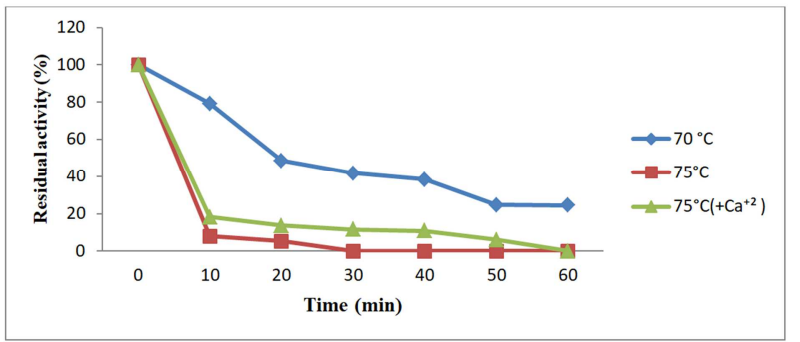

Figure 4. The thermostability of the bacterial enzyme with or without $\mathrm{Ca}^{+2}$.

\subsection{Thin layer Chromatographic (TLC) Analysis of Reaction Products}

TLC analysis of the starch hydrolysate produced by BACC 2107 amylase showed production of glucose, maltose, maltotriose, and different types of oligosaccharides indicating that it is an endo-acting alpha-amylase (Figure 5).

a) G1-Glucose

b) G2-Maltose

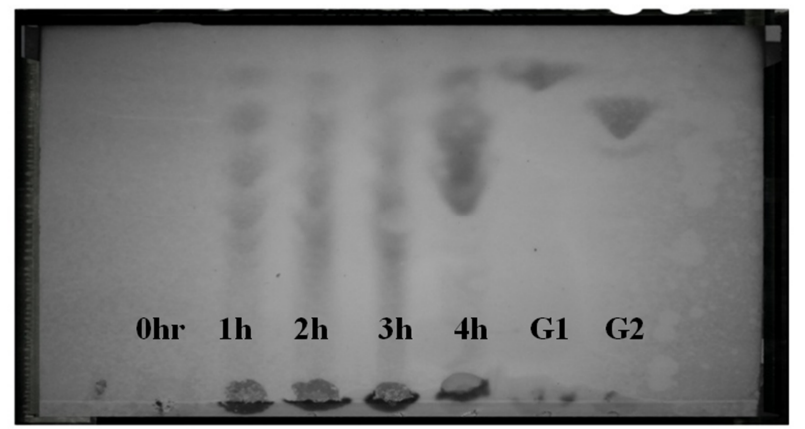

Figure 5. Spots developed from starch hydrolysatese on TLC by the action of bacterial amylase. 


\subsection{Optimization of Culture Conditions for Amylase Production}

\subsubsection{Time Course of Enzyme Production}

Amylase production by BACC 2107 through SSF reached to maximum production at $120 \mathrm{~h}$ of incubation (Figure 6) after which enzyme production declined.

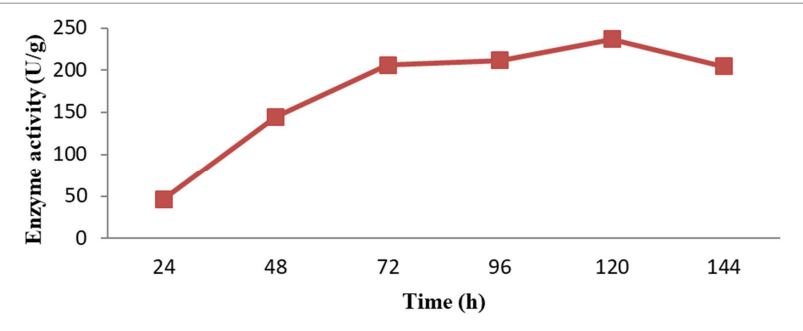

Figure 6. Time course of enzyme production by BACC 2107.

\subsubsection{Effect of Moisture Level on Enzyme Production}

The optimum moisture level for alpha-amylase production by BACC 2107 was observed at a moisture level of $75 \%$ (Figure 7). At lower moisture level enzyme production was low.

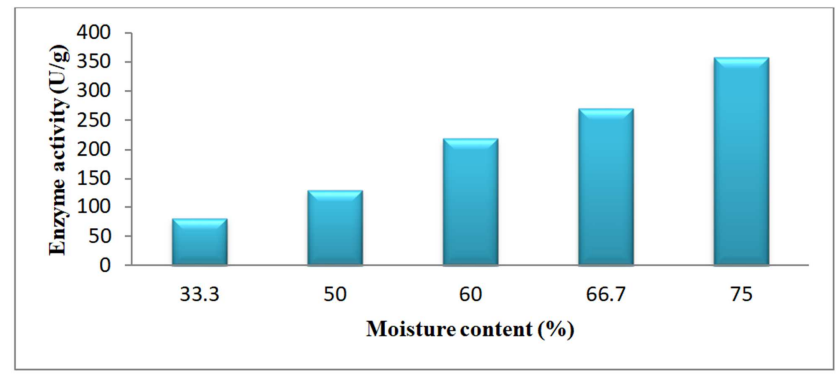

Figure 7. The moisture level of SSF for enzyme production of BACC 2107.

\subsubsection{Effect of Nitrogen Source on Enzyme Production}

Amylase production by isolate BACC 2107 was slightly higher in the presence of an organic nitrogen supplement peptone (Figure 8). However, enzyme production in the presence of other nitrogen supplements or in the absence of any nitrogen supplement showed no significant difference.

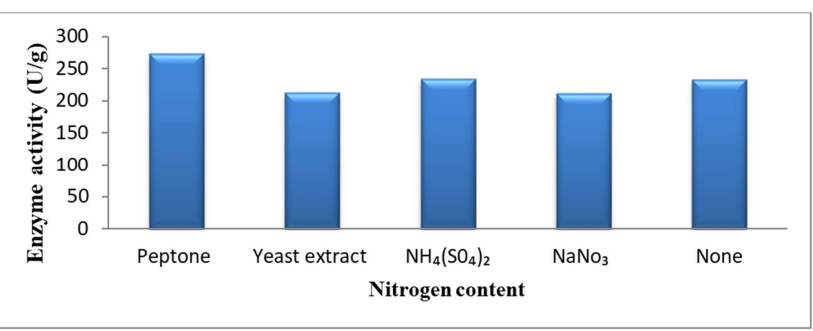

Figure 8. Effect of nitrogen source on alpha amylase production.

\subsection{Enzyme Hydrolysis of Raw Starch}

A $25 \%(\mathrm{w} / \mathrm{v})$ paste was hydrolyzed using $22.8 \mathrm{U}$ of alphaamylase at $70^{\circ} \mathrm{C}$. After $3 \mathrm{~h}$ incubation

$10.85 \mathrm{U}$ malt enzyme ( $\beta$-amylase) was added and incubated at $60^{\circ} \mathrm{C}$ for a further $1 \mathrm{~h}$. Thus after $4 \mathrm{~h}$ of incubation the enzyme released $413.27 \mu \mathrm{mol} / \mathrm{ml}$ of reducing sugar equivalents corresponding to $27.90 \%$ hydrolysis of raw starch (Figure 9)

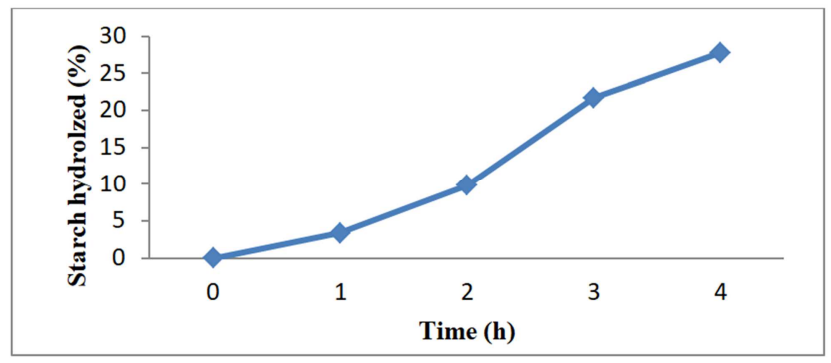

Figure 9. A profile of hydrolysis by BACC2107 enzyme against incubation period.

\subsection{Drop in Starch Viscosity}

The viscosity of starch hydrolysates produced by alpha amylase enzyme was determined by comparing the volume of the starch hydrolysates for down flow speed within 9 second. Based on this, $2.9 \mathrm{ml}$ of a starch hydrolysate which were incubated for $4 \mathrm{~h}$ was able to follow in 9 second (Figure 10).

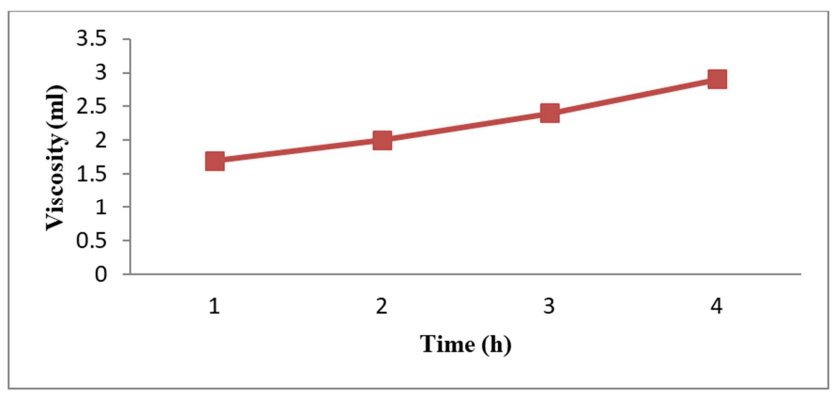

Figure 10. A profile of viscosity starch hydrolyzed by BACC 2107 enzyme.

\section{Discussion}

Amylases are among the most important enzymes for industrial application, with applications in different industrial processes [40]. The existence of diverse applications indicates the need for amylases having different properties. The production of amylases can be carried out by submerged fermentation $(\mathrm{SmF})$ or through solid state fermentation (SSF). Submerged fermentation has been a traditionally used method for the production of amylolytic enzymes. Whereas, solid state fermentation involves growth in the absence of free flowing water using cheap agro industrial wastes. Thus, SSF involves low capital investment for machinery and substrate making preferred technology for developing countries.

In addition to low capital cost, some of the advantages of solid-state fermentation include lower levels of catabolic repression and end product inhibition, low wastewater output, better product recovery, and high quality production [41]. Enzyme production under SSF is affected by various physical and chemical parameters such as temperature, $\mathrm{pH}$, period of incubation, carbon sources acting as inducers, surfactants, 
nitrogen sources, phosphate, different metal ions, moisture and agitation with regards to SSF. Amylase production by isolate BACC 2107 reached to the maximum at $120 \mathrm{~h}$ growth In most bacterial isolates enzyme production starts at around the logarithmic stage of the growth and reaches to maximal point at the stationary growth phase [35]. In the case of the BACC 2107 enzyme, the increment of incubation period beyond $120 \mathrm{~h}$ led to a decrease in enzyme production could be because of depletion of essential nutrients or due to accumulation of toxic substance produces.

Moisture is one of the most important parameters affecting enzyme production through SSF [42]. For isolate BACC 2107 , the highest enzyme production was observed at $75 \%$ (v/w) moisture level (Figure 7). Some researchers reported that at high moisture content substrate porosity is reduced thus or limiting the transfer of oxygen in the particle [43]. However, for isolates BACC 2107 enzyme production progressively increased with increasing moisture level. It has been proposed that at high moisture content solubility of nutrients of substrate particle is high causing a better facility for utilization of the substrate by microorganisms [44, 45].

Another parameter that determines enzyme under SSF addition of nitrogen supplements. The requirement of a specific nitrogen source differs from organism to organism. From all the nitrogen sources, BACC 2107 showed the highest enzymatic production for the organic nitrogen source which is peptone $(273.58 \mathrm{U} / \mathrm{g})$ (Figure 8). Some studies showed that organic nitrogen sources are preferred for the production of $\alpha$-amylase than inorganic nitrogen sources [46] Organic nitrogen sources contain readily available amino acids and peptides that are easily taken by the cell directly and incorporated into protein or changed into other cellular nitrogenous constitutes [47].

Peptone is the richest nitrogen source among other organic nitrogen sources. It is also rich in vitamins and other growth stimulating compounds [48]. However, the reason why amylase production was low in the presence of yeast extract (213 U/g) is not clear. Other authors have also reported that peptone resulted in an increased enzyme production while yeast extract exhibited no effect on alpha amylase production [49]. Aiyer (2004) also reported that peptone is the better nitrogen source for enzyme production by $B$. licheniformis SPT 278 than ammonium hydrogen phosphate [50]. When the SSF was supplemented with inorganic nitrogen content $\left(\mathrm{NaNO}_{3}\right)$, the organism showed $(212.03 \mathrm{U} / \mathrm{g})$ in the enzymatic production (Figure 8). Inorganic nitrogen sources have a less complex nitrogen content which makes the cell spend more energy and time in synthesizing amino acids for protein synthesis.

In starch degrading industries the rate of hydrolysis of starch by amylase enzyme depends on many process conditions such as $\mathrm{pH}$, temperature, stability, nature of substrate, substrate concentration, enzyme concentration, presence of $\mathrm{Ca}^{2+}$ ions, and other stabilizing agents [43]. On the basis of a temperature profile of the BACC 2107 amylase enzyme, in the absence of $5 \mathrm{mM} \mathrm{Ca}^{2+}$ the highest residual activity was observed when the enzyme was incubated at $70^{\circ} \mathrm{C}$ (Figure 3). This is because, when the temperature increases the rate of the enzyme activity will be high because substrates collide with active sites of the enzyme more frequently as the molecules move rapidly [51]. However, the enzyme activity starts to decline when it reaches $75^{\circ} \mathrm{C}$. Some evidence shows that the activity of an enzyme is dependent upon enzyme flexibility [52]. Enzyme flexibility could be affected due to an increment of temperature on the covalent and hydrogen bonds of the enzyme.

The chemical bonds that make up the shape of the enzyme and enzymes' function is related to its shape; thus, the temperature increment causes the weaker hydrogen and ionic bonds of the enzymes to be broken resulting a conformational change in the active site of the enzyme causing a decrement in the activity of the enzyme [51]. The activity of an enzyme can be demonstrated at temperatures below the glass transition where mobility does not occur but catalytic-center activities are very low [53]. In the presence of $5 \mathrm{mM} \mathrm{Ca}^{2+}$ the activity of the enzyme in the temperature range $65^{\circ} \mathrm{C}-75^{\circ} \mathrm{C}$ was relatively similar. This implies that calcium ions have the ability to stabilize the conformational structure of the catalytic and/or substrate binding site [43]. Some of the findings show that $\mathrm{Ca}^{2+}$ ion has the ability to increase the $\alpha$-amylase activity of an alkaliphilic Bacillus sp. ANT-6 [40]. The other challenge in the starch degrading industry is the stability of an enzyme. Scientifically, the stability of an enzyme is the result of a delicate balance between large stabilizing (nature of an enzyme) and large destabilizing forces which could be the increment of temperature. Based on this, the thermostability of alphaamylase in the absence of $5 \mathrm{mM} \mathrm{Ca}^{2+}$ the enzyme was able to sustain $24.51 \%$ of its original activity at $70^{\circ} \mathrm{C}$, and at $75^{\circ} \mathrm{C}$ the enzyme only retains $5 \%$ of its original activity within 20 min of incubation (Figure 4).

Some reported that the conformational stability of an enzyme is the result of a compromise between two opposing factors: flexibility, for the catalytic function of the enzyme and rigidity, for conformational stability [54]. In the case of the BACC 2107 enzyme, the enzyme resulted in a conformational change of the active site after $20 \mathrm{~min}$ incubation (denaturation) at $75^{\circ} \mathrm{C}$. It has been reported that the conformational stability of an enzyme depends upon a stabilizing force arising from a large number of weak interactions between the hydrophobic residues, which are opposed by almost an equal large destabilizing force due mostly to conformational entropy [52]. The rigidity of the hydrophobic interaction protects them from unfolding and preserves their catalytically active structure [54]. Soni et al., (2003), reported the $\alpha$-amylase of a Bacillus species to have an optimum temperature $70^{\circ} \mathrm{C}$ and thermal stability were greater than $60^{\circ} \mathrm{C}$ [55].

On the other hand, in the presence of $5 \mathrm{mM} \mathrm{Ca}^{2+}$ the enzyme retained $6.05 \%$ of its original activity at $75^{\circ} \mathrm{C}$ within 50 min of incubation (Figure 5). It is well documented that; calcium ions enhance the thermostability of bacterial amylase by binding on the surface of the protein so that it salts out the hydrophobic residues. Eventually, the enzyme adopts a 
compacted structure and reduced the flexibility of the enzyme [56, 57]. Some researchers reported that the thermostabilities of Bacillus licheniformis CUMC 305 was as high as $4 \mathrm{~h}$ at $100^{\circ} \mathrm{C}$ have been reported [58]. In general, the enzyme was a thermostable enzyme. In the starch industry, starch slurry is heated in a jet cooker at a temperature range of $100-175^{\circ} \mathrm{C}$ in order to disrupt the starch granules and release the amylose and amylopectin into the water (gelatinization). Then the heated starch slurry is passed directly into a hydrolysis reactor for further enzymatic treatment (liquefaction). To make the process economical, aamylases used for this application are preferred to be active and stable at the high temperatures of gelatinization (100 $\left.110^{\circ} \mathrm{C}\right)$ and liquefaction $\left(70-90^{\circ} \mathrm{C}\right)$ [43]. This shows that amylase BACC 2107 has a good potential to be used in the process of starch liquefication.

$\mathrm{pH}$ is another factor affecting the rate of hydrolysis of starch by a-amylase. In a starch degradation process, the starch slurry containing (30-40\%) dry solids is cooked in a jet cooker. The enzyme will be added after the starch has been cooked and cooled, in this process, the $\mathrm{pH}$ may be in the range of 2- 5 [12]. Every enzyme has its own optimum $\mathrm{pH}$. In the case of alpha amylase of BACC 2107, the enzyme was able to maintain its optimum activity in the $\mathrm{pH}$ range of $4.0-$ 8.0 and the highest activity of the enzyme was observed at pH 5.0 (Figure 2). This indicates that $\mathrm{pH} 5.0$ is an optimum $\mathrm{pH}$ for amylase BACC 2107.

The optimum $\mathrm{pH}$ of an enzyme means that the concentration of $\mathrm{H}^{+}$ions in the solution is the right concentration to give the tertiary structure the best overall shape. As stated, that an important part of catalysis in the active site relies on charged groups of on the R-groups of the amino acids that make up the active site. So, increasing or decreasing the $\mathrm{pH}$ (the concentration of $\mathrm{H}^{+}$ions) will alter the charges that are around the active site. This would happen because more $\mathrm{H}^{+}$ions would be attracted towards any negatively charged groups that are in the active site (amino acids form part of the active sites and are negatively charged. These $\mathrm{H}^{+}$ions are therefore attracted to these groups and cluster around them. By doing this, it interferes with the binding of the substrate to the active site and it, therefore, changes the rate of activity of the enzyme - the rate of an enzyme controlled reaction). Based on this, when the $\mathrm{H}^{+}$ions of the solution decrease the activity of amylase BACC 2107 starts to decrease. The excessive increment and decrement of $\mathrm{H}^{+}$ions concentration in the solution can cause an effect on the intramolecular forces and change the enzyme's shape -potentially to the point where it is rendered ineffective. In conclusion, $\alpha$-amylase of BACC 2107 is an acidic thermostable enzyme.

In the starch degradation process, the gelatinization of starch requires a high-energy input forming starch-based products with an increased production cost. The hydrolysis of raw starch below gelatinization temperatures has gained an important point of view in energy costs, effective utilization of natural resources, and viscosity problems. In the starch liquefying and saccharifying industry, the sweetness of a starch syrup depends on the degree of hydrolysis, and complete hydrolysis of starch results in the formation of only glucose or dextrose. The amount of dextrose in syrup is given by the DE (amount of reducing equivalents expressed as glucose per unit dry weight). As far as reducing power is concerned, BACC 2107 amylase was able to hydrolyze a $25 \%(\mathrm{w} / \mathrm{v})$ of gelatinized starch in 4 $\mathrm{h}$ of incubation and released $413.3 \mu \mathrm{mol} / \mathrm{ml}$ of reducing sugar equivalents corresponding to $27.9 \%$ hydrolysis of starch. This implies that when the incubation period increases the enzyme would be able to catalyze the hydrolysis of internal $\alpha$ - 1,4-glycosidic linkages of the starch into a low molecular weight product, such as glucose, maltose, and maltotriose units [43]. This indicates that the amylase is a liquefying and saccharifying enzyme [59]. A thermostable alpha-amylase of Bacillus $s p$. I-3 was also reported for the hydrolysis of raw potato starch at a concentration of $12.5 \%$ within $12 \mathrm{~h}$ [60]. Therefore, enzymes that are capable of digesting raw potato starch are economically attractive for the increased range of starch sources for direct saccharification [33].

The other main problem in starch liquefying and the saccharifying industry is viscosity. Viscosity is a result of further heating of a starch granule above its gelatinization temperature. In this research, the viscosity of the raw starch was measured by comparing the volume of starch hydrolysates produced by alpha-amylase for downflow speed within 9 seconds. The result shows that in the presence of $\alpha$ amylase the viscosity of the starch starts to drop as the incubation period increases as result the fluidity of a starch increases (Figure10). Since the viscosity of starch is related mainly to the swelling of amylopectin molecules and the reduction of viscosities of hydrolyzed starches in relation to the original starches can be explained by the enzyme action on the amylose and amylopectin molecules [61]. Thus, by using the amylase enzyme as a thinning agent when alphaamylase starts to hydrolyze the gelatinized starch, the swollen granules will be converted into another molecule or degraded into their lowest form (unit). Some of the scientific reports indicate that the viscosity of starch is essentially the principal measure of the potential application of starch in the industry $[62,63]$. Some of the researchers also indicated that the concentration, temperature, volume fraction of the swollen granules, the deformability of the granules, and the degree of molecular entanglement affect the viscosity of starch pastes during pasting $[64,65]$.

\section{Conclusion and Recommendation}

The recent development of industrial biotechnology has promoted a renewed interest in an investigation of microorganisms capable of producing an extracellular enzyme. East Africa region has a unique microbial diversity that could serve as a source of novel enzymes for industrial application. Alpha-amylase of BACC 2107 has a property of low $\mathrm{pH}$ activity and a thermo stability $\left(70^{\circ} \mathrm{C}-75^{\circ} \mathrm{C}\right)$ and thermal activity $\left(60^{\circ} \mathrm{C}-75^{\circ} \mathrm{C}\right)$ that can also be enhanced with 
the addition of $5 \mathrm{mM} \mathrm{Ca}{ }^{2+}$. Based on this, the amylase enzyme of BACC 2107 could be a good candidate for use for starch liquefaction and saccharification processes. Additionally, the presence of abundantly available year round agricultural by products such as wheat bran in the country like Ethiopia could enable the production of amylase enzyme by BACC 2107. Since East Africa is a potential region for the production of starch based products the maximal production of amylase using easily available carbon sources coupled with a rapid starch hydrolyzing ability of the enzyme is one of the great economic advantages. The ability of Alpha amylase of BACC 2107 to hydrolyze different types of botanical source like potato makes it a favorable enzyme for the production of candies, jams, jellies, etc. It can also be used to supplement malt amylase in breweries and the hydrolysates produced by this enzyme can also be used as a carbon source in the fermentation process, which makes BACC 2107 strain a potential candidate for the production alpha amylase enzyme acceptable by the commercial standard of enzyme production. Therefore, it is recommended that the enzyme should be characterized further, purified and produced on large scale to be easily accessible for large scale industrial applications. Additionally, the gene coding for BACC 2107 the strain should be cloned and modify some of the properties through protein engineering.

\section{References}

[1] Sajilata, M., Singhal, R. and Kulkarni, P. (2006). Resistant starcha review. Compreh. rev. food sci.. food saf. pp. 5 (1): 1-17.

[2] Van Der Maarel, M., Van Der Veen, B., Uitdehaag, J., Leemhuis, H. and Dijkhuizen, L. (2002). Properties and applications of starch-converting enzymes of the $\alpha$-amylase family. J. biotechno. pp. 94 (2): 137-155.

[3] Muazu, J., Girbo, A., Usman, A. and Mohammed, T. (2012a). Preliminary studies on Hausa potato starch II: The binding properties. J. Pharm. Sci. Tech. pp. 4: 965-971.

[4] Gebre-Mariam Tsige and Schmidt, P. (1996a). Isolation and physicochemical properties of Enset starch. Starch/Starke. pp. 48: $208-214$.

[5] Gebre-Mariam Tsige and Schmidt, P. (1998). Some physicochemical properties of dioscorea starch from Ethiopia. Starch/Stärke. pp. 50: 241-246.

[6] Adane Million, Gamal Mohsen and Gebre-Mariam Tsige (2006). Evaluation and optimization of godare starch as a binder and disintegrant in tablet formulation. Ethiop. Pharm. J. pp. 24: 106-115.

[7] Nigussie Temesgen, Endale Assefa and Gebre-Mariam Tsige (2006). Isolation, characterization and evaluation of binding and disintegrate effects of anchote starch in paracetamol tablet formulation. M. Sc Thesis, School of Pharm. A. A. U.

[8] Paulos Getachew, Endale Assefa, Bultosa Girma and GebreMariam Tsige (2009). Isolation and physicochemical characterization of cassava starches obtained from different regions of Ethiopia. Ethiop. Pharm. J. pp. 27: 42-54.
[9] Mohammed Kumare, Endale Assefa and Gebre-Mariam Tsige (2007). Isolation, acetylation and physicochemical characterization of kottee harree (dioscoreabulbifera) starch, M. Sc Thesis, School of Pharm. A. A. U.

[10] Wuttisela, K., Shobsngob, S., Triampo, W. and Triampo, D. (2008). Amylose/amylopectin simple determination in acid hydrolyzed tapioca starch. J. Chilean Chem. Soci. pp. 53 (3): 1565-7.

[11] Reddy, N. S., Nimmagadda, A. and Rao, K. S. (2003). An overview of the microbial $\alpha$-amylase family. African journal of biotechnology. pp. 2 (12): 645-648.

[12] Aiyer, P. (2005). Amylases and their applications. Afr. J. Biotechnol.pp. 4 (13).

[13] Muluye Teka (2006). Amylases of potential industrial application from microbial sources. M. Sc. Thesis. Department of Bio. A. A. U. A. A. Ethio. pp.: 59.

[14] Cherry, H., Hossain, M. and Anwar, M. (2004). Extracellular glucoamylase from the isolate Aspergillus fumigatus. Pakit. $J$. Biol. Sci. pp. 7 (11): 1988-1992.

[15] de Souza, P. and Magalhães, P. (2010). Application of microbial $\alpha$-amylase in industry-a review. Braz. J. Micro. pp. 41: 850-861.

[16] Naidu, M. (2013). Bacterial Amylase A Review. Inter. j. Pharm. Biol. Arc. pp. 4 (2).

[17] Rodriguez, V., Alameda, E., Gallegor, J. and Requena, A. (2006). Modification of the activity of $\alpha$-amylase from Bacillus licheniformis by several surfactants. Electro. $J$. Biotechno. pp. 9 (5): 10-16.

[18] Kirk, O., Borchert, T. and Fuglsang, C. (2002). Industrial enzyme applications. Current opi. biotechno. pp. 13 (4): $345-$ 351 .

[19] Tonkova, A. (2006). Microbial starch converting enzymes of the $\alpha$-Amylase family. In: Micro. Biotechno. Horticul. pp.: 421-472.

[20] Reddy, N., Nimmagada, A. and Sambasivarac, R. (2003). An over view of the Microbial alpha amylase Minireview. Afri. $J$. Biotechnol.pp. 2 (27): 645-648.

[21] Sajedi, R., Naderi-Manesh, H., Khajeh, K., Ahmadvand, R., Ranjbar, B., Asoodeh, A. and Moradian, F. (2005). A Caindependent $\alpha$-amylase that is active and stable at low $\mathrm{pH}$ from the Bacillus sp. KR-8104. Enzyme and Micro. Techno. pp. 36 (5-6): 666-71.

[22] Vaseekaran, S., Balakumar, S. and Arasaratnam, V. (2010). Isolation and identification of a bacterial strain producing thermostable $\alpha$-amylase. Trop. Agri. Resea. pp. 22 (1): 1-11.

[23] Alemayhu, F. (2019). Isolating thermostable amylase producing bacteria from hot spring water in Senbete, Ethiopia and optimization of its production (Doctoral dissertation).

[24] Mamo, G. and Gessesse, A. (1997). Thermostable Amylase production by immobilize thermophilic Bacillus sp. Biotechnol. Techn. pp. 11: 447-50.

[25] Ryckeboer, J., Mergaert, J., Coosemans, J., Deprins, K. and Swings, J. (2003). Microbiological aspects of biowaste during composting in a monitored compost bin. Journal of Applied microbiology. Pp. 94 (1): 127-137. 
[26] Sanni, A. I., Morlon-Guyot, J. and Guyot, J. P. (2002). New efficient amylase-producing strains of Lactobacillus plantarum and L. fermentum isolated from different Nigerian traditional fermented foods. International journal of food microbiology. pp. 72 (1-2): 53-62.

[27] McTigue, M., Kelly, C., Doyle, E. and Fogarty, W. (1995). The alkaline amylase of the alkalophilic Bacillus sp. IMD 370. Enzyme Microb. Technol.pp. 17: 570-3.

[28] Morlon-Guyot, J., Guyot, J. P., Pot, B., De Haut, I. J. and Raimbault, M. (1998). Lactobacillus manihotivorans sp. nov., a new starch-hydrolysing lactic acid bacterium isolated during cassava sour starch fermentation. International Journal of Systematic and Evolutionary Microbiology. pp. 48 (4): 11011109.

[29] Babu, K. and Satyanarayana, T. (1995). $\alpha$-Amylase production by thermophilic Bacillus coagulans in solid state fermentation. Process Biochem. pp. 30 (4): 305-309.

[30] Bertrand, T., Fredric, T. and Robert, N. (2004). Production and partial characterization of a thermostable amylase from Ascomycetes yeast strain isolated from starchy soil. McGrawHill Inc. New York. pp.: 53-55.

[31] Lo, H., Lin, L., Chen, H., Hsu, H. and Chang, C. (2001). Enzymatic properties of a SDSresistant Bacillus sp. TS-23 aamylase produced by recombinant Escherichia coli. Process Biochem. pp. 36: 743-50.

[32] Egas, M., da Costa, M., Cowan, D. and Pires, E. (1998). Extracellular a-amylase from Thermus filiformis Ork A2: purification and biochemical characterization. Extremo. pp. 2: 23-32.

[33] Gashaw Mamo and Amare Gessesse (1999a). Production and characterization of two raw starch digesting thermostable alpha amylases from thermophilic Bacillus sp. Enz. Microbial. Technol. pp. 25: 433-438.

[34] Ramesh, M. and Lonsane, B. (1990). Critical importance of moisture content of the medium in alpha-amylase production by Bacillus licheniformis M27 in solid-state fermentation system. App. Microbiol. Biotechno. pp. 33 (5): 501-5.

[35] Meer, V. and Saramma, A. (2004). Alkaline Proteases From Bacteria Isolated From Cochin Estuary (Doctoral Dissertation, Cochin University Of Science And Technology).

[36] Akcan, N., Serin, B. and Uyar, F. (2012). Production and optimization parameters of amylase from Bacillus subtilis RSKK96 under solid state fermentation. Chem. biochem. enginee quart. pp. 26 (3): 233-9.

[37] Buttimer, E. and Briggs, D. (1998). Improved extraction and assay of $\beta$-amylase from barley and malt. J. insti. Bre. pp. 104 (3): $157-164$.

[38] Legin, E., Copinet, A. and Duchiron, F. (1998). A single step high temperature hydrolysis of wheat starch. Starch/Staerke. pp. $50(2-3): 84-9$.

[39] Mamo, G. and Gessesse, A. (1999). Production of raw starch digesting amyloglucosidase by Aspergillus sp. GP-21 in solid state fermentation. J. Ind. Microbiol. Biotechnol. pp. 22: 6226.

[40] Burhan, A., Nisa, U., Gökhan, C., Ömer, C., Ashabil, A. and Osman, G. (2003). Enzymatic properties of a novel thermostable, thermophilic, alkaline and chealator resistant amylase from an alkaliphilic Bacillus sp. isolate ANT-6. $J$.
Process Biochem. pp. 38: 1397-1403.

[41] Pandey, A. (1992). Recent process developments in solid-state fermentation. Process Biochem. pp. 27: 109-117.

[42] Pandey, A., Nigam, P., Soccol, C., Soccol, V., Singh, D. and Mohan, R. (2000). Advances in microbial amylases. Biotechnol. Appl. Biochem. pp. 31: 135-152.

[43] Sivaramakrishnan, S., Gangadharan, D., Nampoothiri, K., Soccol, C. and Pandey, A. (2006). $\alpha$-Amylases from microbial sources-an overview on recent developments. Food Technol. Biotechnol. pp. 44 (2): 173-184.

[44] Anto, H., Trivedi, U. and Patel, K. (2006). Glucoamylase production by solid-state fermentation using rice flake manufacturing waste products as substrate. Bioresour. Technol. pp. 97: 1161-1166.

[45] Ibrahim, S., El Amin, H., Hassan, E. and Sulieman, A. (2012). Amylase Production on Solid State Fermentation by Bacillus spp. Food and Pub. Heal. pp. 2 (1): 30-35.

[46] Gupta, R., Gigras, P., Mohapatra, H., Goswami, V. and Chauhan, B. (2003). Microbial $\alpha$ - amylases: a biotechnological perspective. Process biochem. pp. 38 (11): 1599-1616.

[47] Mongi, F., Edward, C., William, H., Gwang-Hoon, G. and Almadidy, A. (2005). Influence of culture parameters on biological hydrogen production by Clostridium saccharoperbutylacetonicum ATCC27021. World J. Microbiol. Biotechnol.pp. 21: 855-862.

[48] Wang, Y., Nema, S. and Teagarden, D. (2010). Protein aggregation Pathways and influencing factors. Int. J. Pharm. pp. 390: 89-99.

[49] Tanyildizi, M., Ozer, D. and Elibol, M. (2005). Optimization of $\alpha$-amylase production by Bacillus sp. using response surface methodology. Process Biochem. pp. 40: 2291-2296.

[50] Aiyer, P. (2004). Effect of C: N ratio on alpha amylase production by Bacillus licheniformisSPT 278. Afr. J. Biotechnol.pp. 3: 519-522.

[51] Reece, J., Lisa A., Urry, L., Cain, M., Wasserman, S., Minorsky, P. and Jackson, R. (2011). Campbell Biology. Boston: Pearson Edu. pp. 9.

[52] Daniel, R., Dines, M. and Petach, H. (1996). The denaturation and degradation of stable enzymes at high temperatures. Biochem.j. pp. 317 (1): 1-11.

[53] More, N., Daniel, R. and Petach, H. (1995). The effect of low temperatures on enzyme activity. Biochem. j. pp. 305 (1): 1720.

[54] Padayachee, T. (2006). Application of thermostable a-Amylase from Thermomyceslanuginosus ATCC 58157 to nutritionally enhance starch based food (Doctoral dissertation).

[55] Soni, S., Kaur, A. and Gupta, J. (2003). A solid state fermentation based bacterial $\alpha$ - amylase and fungal glucoamylase system and its suitability for the hydrolysis of wheat starch. Process Biochem. pp. 39: 185-192.

[56] Breitung, J., Schmitz, R., Stetter, K. and Thauer, R. (1991). N5, N10- methenyltetrahydromethanopterin cyclohydrolase from the extreme thermophile Methanopyruskandleri: increase of catalytic efficiency $(\mathrm{kcat} / \mathrm{KM})$ and thermostability in the presence of salts. Arch. Microbiol. pp. 156: 517-524. 
[57] Sabour, A. (2002). Stability, activity and binding properties study of $\alpha$-amylase upon interaction with $\mathrm{Ca}^{2+}$ and $\mathrm{Co}^{2+}$. Biologia. Bratislava. 57-Suppl. pp. 11: 221-228.

[58] Krishnan, T. and Chandra, A. K., (1983). Purification and characterization of $\alpha$-amylase from Bacillus licheniformis CUMC305. Applied and Environmental Microbiology. pp. 46 (2): $430-437$.

[59] Ayalew Damte (2011). Production of Alkaline Amylase from a Facultatively Anaerobic Alkaliphilic bacteria. M. Sc Thesis.

[60] Soni, N. Goyal, J. K. Gupta, S. K. (2005). A novel raw starch digesting thermostable a-amylase from Bacillus sp. I-3 and itsuse in the direct hydrolysis of raw potato starch. Enzyme Microb. Technol. 37: 723-734.

[61] Richardson, G., Langton, M., Bark, A. and Hermansson, A. M. (2003). Wheat starch gelatinization-the effects of sucrose, emulsifier and the physical state of the emulsifier. StarchStärke. pp. 55 (3-4): 150-161.

[62] Sarker, M., Elgadir, M., Ferdosh, S., Akanda, M., Aditiawati, P., and Noda, T. (2013). Rheological behavior of starch-based biopolymer mixtures in selected processed foods. Starch/Staerke. pp. 65 (1-2): 73-81.

[63] Gryszkin, A., Zieba, T., Kapelko, M. and Buczek, A. (2014). Effect of thermal modifications of potato starch on its selected properties. Food Hydro. pp. 40: 122-127.

[64] Doublier, J. (1990). Rheological properties of cereal carbohydrates. In Dough Rheology and Baked Product Texture. New York: Van Nostr. Rein. pp.: 111-156.

[65] Noosuk, P., Hill, S., Pradipasena, P., and Mitchell, J. (2003). Structure-viscosity relationships for Thai rice starches. Starch/Starke. pp. 55: 337-344. 